\title{
MENDORONG TRANSPARANSI DAN AKUNTABILITAS PENGATURAN KEUANGAN PARTAI POLITIK
}

\author{
Sekar Anggun Gading Pinilih* \\ Fakultas Hukum Universitas Diponegoro \\ J1. Prof. H. Soedarto, S.H Tembalang Semarang
}

\begin{abstract}
A political party needs financial assistance from members, the state or the donations to realize their functions. A lot happening raising and management of funds that are not based on transparency and accountability principle. Transparency and accountability principle of party finances can be achieved by requiring each party financial reports on the sources of funds received, and the financial reports of the elections. It is necessary penalties for parties who are late or even not make reports, which institutions are given the task of overseeing the financial reports, and institutions that enforce sanctions.
\end{abstract}

Keywords: transparency, accountability, regulation, finance, political party.

\section{Intisari}

Partai politik memerlukan bantuan keuangan dari anggota partai itu sendiri, negara atau sumbangan pihak lain untuk mewujudkan fungsi-fungsinya. Banyak terjadi penggalangan dan pengelolaan dana oleh partai yang tidak dilandasi dengan prinsip transparansi dan akuntabilitas. Prinsip transparansi dan akuntabilitas keuangan partai dapat dicapai dengan cara mewajibkan setiap partai membuat laporan keuangan atas sumber dana yang diterima, dan laporan keuangan Pemilu. Perlu diatur juga mengenai sanksi bagi partai yang terlambat atau bahkan tidak membuat laporan keuangan, serta lembaga mana yang diberikan tugas untuk mengawasi laporan keuangan partai dan lembaga yang menegakkan sanksi tersebut.

Kata Kunci: transparansi, akuntabilitas, pengaturan, keuangan, partai politik.

\section{Pokok Muatan}

A. Pendahuluan 70

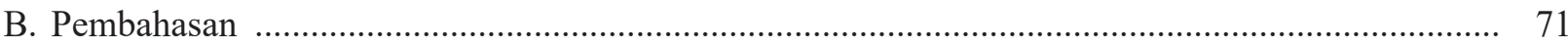

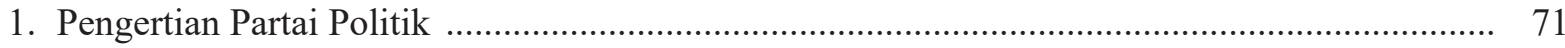

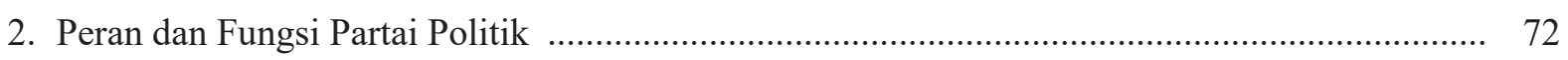

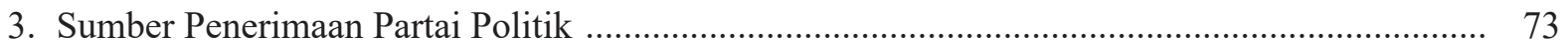

4. Transparansi dan Akuntabilitas Pengatur $\neg$ an Keuangan Partai Politik ...................................... 75

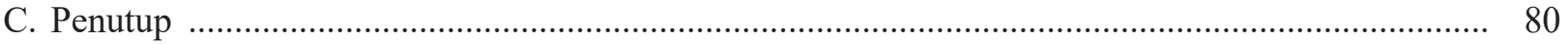

Alamat korespondensi: sekar.anggun.gp@gmail.com. 


\section{A. Pendahuluan}

Keikutsertaan dalam pemilihan umum merupakan salah satu fungsi partai politik. Fungsi utama (alasan keberadaan) partai politik bukan mencari dan mempertahankan kekuasaan melalui pemilu, melainkan sebagai "jembatan antara masyarakat dengan negara". Fungsi jembatan ini dilaksanakan melalui berbagai kegiatan, yaitu melakukan rekrutmen warga negara menjadi anggota partai politik; melaksanakan pendidikan politik bagi warga negara; melalukan kaderisasi terhadap calon pemimpin; menjadi saluran partisipasi politik warga negara; menyalurkan aspirasi dan kepentingan warga negara; menampung dan merumuskan aspirasi dan kepentingan warga negara itu menjadi rancangan keputusan politik (menyangkut kebijakan publik dan/atau pengusulan seseorang atau lebih menjadi penyelenggara negara) berdasarkan ideologi partai; memperjuangkan rancangan keputusan politik tersebut menjadi keputusan politik melalui lembaga legislatif dan eksekutif; melaksanakan keputusan politik itu kalau dipercaya rakyat untuk menjalankan pemerintahan atau manakala kalah dalam pemilu berperan menjadi pihak oposisi terhadap partai/koalisi partai yang memerintah, baik dalam pembuatan legislasi maupun anggaran; dan mengkomunikasikan apa yang dikerjakan kepada para anggota dan konstituen. Oleh karena itu, diperlukan sejumlah dana (keuangan) partai politik untuk melaksanakan fungsi utama tersebut. Hal ini senada dengan apa yang dikemukakan oleh Khayyam Z. Paltiel tentang tujuan penggunaan dana dalam sistem kepartaian yang kompetitif: keikutsertaan dalam pemilu, memelihara aktivitas organisasi antar-pemilu, dan menyediakan bantuan riset dan bantuan lain kepada kepemimpinan partai dan kepada para kader partai yang duduk dalam lembaga perwakilan. ${ }^{1}$

Pada tahun 1999, Indonesia membuat kebijakan liberalisasi politik yang dramatis dengan membuka kran pendirian partai politik. Berawal dari kebijakan tersebut, lahirnya banyak partai politik yang sekarang mendominasi wajah politik di ranah publik di samping tiga partai dari masa Orde Baru, yaitu Golkar, PPP, dan PDI-P. Akan tetapi, kebijakan liberalisasi politik kepartaian tidak diikuti oleh adanya kerangka peraturan perundangan-undangan yang jelas dan tegas serta implementasi yang efektif. Selain itu, lemahnya kapasitas organisasi partai menjadi faktor penting lainnya yang terabaikan. Akibatnya, partai politik bergerak tanpa koridor hukum yang tegas dan sumber daya manusia yang unggul yang mengakibatkan partai menjadi entitas politik yang kuat tapi tak terkendali di iklim politik yang liberal. Akhirnya, batasan etika dan hukum diterobos partai tanpa memikirkan konsekuensinya. Hal ini sangat terlihat dengan upaya partai berlomba-lomba menumpuk pundi-pundi uang untuk menjalankan roda organisasi partai. Pengurus partai dan pejabat publik dari partai menggunakan berbagai manuver untuk membawa pundit-pundi uang ke partai politik. Tatacara praktek penggalangan dana yang tidak dilandasi dengan prinsip transparansi dan akuntabilitas mengakibatkan munculnya berbagai kasus dugaan korupsi yang dilakukan orang partai politik. ${ }^{2}$ Banyak kasus korupsi yang terungkap menunjukkan bahwa dana dari kejahatan itu digunakan untuk kepentingan pemenangan pemilu, baik di tingkat nasional maupun lokal. Hal ini menjadi salah satu penyebab dari buruknya kualitas Demokrasi di Indonesia.

Praktek pemanfaatan dana publik secara tidak transparan dan akuntabel oleh partai politik tidak hanya menjadi karakteristik dari penyalahgunaan kekuasaan publik yang khas Indonesia, atau negaranegara dengan sistem demokrasi baru (tetapi masih lekat karakter dan praktek non-demokratis) seperti Thailand, Filipina, atau contoh dari negara-negara Amerika Latin seperti Meksiko dan Brazil, tetapi

Ramlan Surbakti dan Didik Supriyanto, 2011, Pengendalian Keuangan Partai Politik, Kemitraan bagi Pembaruan Tata Pemerintahan, Jakarta, hlm. 1.

Very Junaidi, et al., 2011, Anomali Keuangan Partai Politik: Pengaturan dan Praktek, Kemitraan bagi Pembaruan Tata Pemerintahan, Jakarta, hlm. iii-iv. 
juga fenomena yang kerap terjadi pada negara demokrasi mapan dan ekonomi maju seperti Jepang, Taiwan, dan India. ${ }^{3}$ Berdasarkan pengalaman negara demokrasi di dunia, terdapat tiga alternatif sumber dana partai politik, yaitu dari internal partai (iuran anggota, sumbangan kader partai, atau badan usaha yang didirikan oleh partai), dari kalangan swasta (sumbangan dari individu, badan usaha swasta, organisasi dan kelompok masyarakat), dari bantuan keuangan negara (APBN, APBD). ${ }^{4}$ Di Indonesia sendiri telah diatur dalam Undang-Undang Nomor 2 Tahun 2011 Tentang Perubahan Atas UndangUndang Nomor 2 Tahun 2008 Tentang Partai Politik, bahwa setiap partai politik berhak mendapat uang dari tiga sumber, yaitu iuran anggota, sumbangan yang sah menurut hukum, serta bantuan keuangan dari Anggran Pendapatan dan Belanja Negara (APBN) dan Anggaran Pendapatan dan Belanja Daerah (APBD).

Atas berbagai sumber dana yang diterima, sebagian besar partai politik hanya memiliki laporan keuangan yang berasal dari APBN dan APBD. Partai politik cukup taat membuat laporan tersebut karena jika laporan itu tidak dibuat maka dana bantuan keuangan berikutnya akan berkurang. Sayangnya, partai politik sering terlambat dalam memberikan laporan tersebut. Walaupun terlambat, Pemerintah melalui Kementerian Dalam Negeri (Kemendagri) tetap mengucurkan anggaran untuk partai politik pada tahun berikutnya. Persoalan transparansi atas pendanaan partai politik masih menjadi tantangan hingga saat ini. Bagaimanakah sebaiknya pengaturan keuangan partai politik ke depannya sehingga dapat mencapai prinsip transparansi dan akuntabilitas? Harapan publik untuk dapat mengakses dokumen laporan keuangan masih sulit dijamin. Transparansi dan akuntabilitas dalam pengelolaan keuangan partai politik adalah keniscayaan karena sebagai institusi publik partai politik mempunyai peran besar dalam menjaga demokrasi dan mengelola pemerintahan. Pengelolaan dana dalam internal partai sangatlah menentukan eksistensi partai dalam perpolitikan.

\section{B. Pembahasan}

\section{Pengertian Partai Politik}

Partai politik merupakan suatu keharusan dalam kehidupan politik modern yang demokratis. Sebagai suatu organisasi, partai politik secara ideal dimaksudkan untuk mengaktifkan dan mobilisasi rakyat, mewakili kepentingan tertentu, memberikan jalan kompromi bagi pendapat yang saling bersaing, serta menyediakan secara maksimal kepemimpinan politik secara sah dan damai. Secara umum, dapat dikatakan bahwa partai politik adalah suatu kelompok yang terorganisir yang anggota-anggotanya mempunyai orientasi, nilai dan cita-cita yang sama. Tujuan kelompok ini ialah untuk memperoleh kekuasaan politik dan merebut kedudukan politik, biasanya dengan cara konstitusional untuk melaksanakan kebijaksanaan-kebijaksanaan mereka. Menurut Sigmund Neumann dalam karangannya Modern Political Parties, partai politik adalah organisasi dari aktivitas-aktivitas politik yang berusaha untuk menguasai kekuasaan pemerintahan serta merebut dukungan rakyat atas dasar persaingan dengan suatu golongan atau golongan-golongan lain yang mempunyai pandangan yang berbeda. ${ }^{5}$ Dengan demikian, partai politik merupakan perantara yang besar yang menghubungkan kekuatan-kekuatan dan ideologi-ideologi sosial dengan lembaga-lembaga pemerintahan yang resmi dan yang mengkaitkannya dengan aksi politik di dalam masyarakat yang lebih luas.

Austin Ranney menyatakan bahwa "political parties are a special kind of political group" yang memiliki lima karateristik fundamental, sebagai

3 Tim Riset Institute For Strategic Initiatives (ISI), Penggunaan Dana Publik Untuk Kampanye, Hasil Penelitian Tim Riset Institute For Strategic Initiatives (ISI) kerjasama dengan Kemitraan Partnership dan Perludem, Jakarta, hlm. 7.

4 Torang Rudolf Effendi Manurung, "Perkembangan Politik Hukum Pertanggungjawaban Partai Politik Dalam Pengelolaan Bantuan Keuangan Negara Pasca Reformasi”, Jurnal Yustisia, Vol. 91 Januari, April 2015, hlm. 119.

Miriam Budiardjo, 2005, Dasar-dasar Ilmu Politik, Gramedia Pustaka Utama, Jakarta, hlm.162. 
berikut: ${ }^{6}$

a. They are groups of people to whom labels- "Republican", "Communist", "Liberal", and so on- are generally applied by both themselves and others;

b. Some of the people are organized- that is, they deliberately act together to achieve party goals;

c. The larger society recognizes as legitimate the right of parties to organized and promote their causes;

d. In some of their goal promoting activities parties work through the mechanism of representative government;

e. A key activity of parties is thus selecting candidates for elective public office.

Berdasarkan definisi-definisi tentang partai politik di atas, maka basis sosiologis suatu partai politik adalah ideologi dan kepentingan yang diarahkan pada usaha-usaha untuk memperoleh kekuasaan. Tanpa kedua elemen tersebut, maka partai politik tidak akan mampu mengidentifikasi dirinya dengan para pendukungnya. Definisi partai politik di atas juga menunjukkan kedudukan partai politik sebagai:
a. Salah satu wadah atau sarana partisipasi politik rakyat.
b. Perantara antara kekuatan-kekuatan sosial dengan pemerintah.

\section{Peran dan Fungsi Partai Politik}

Dalam kepustakaan ilmu politik, sering dikemukakan bahwa partai politik mempunyai peranan:
a. Dalam proses pendidikan politik; pemimpin bangsa guna mengisi berbagai macam posisi dalam kehidupan bernegara;
b. Sebagai sumber rekrutmen para
c. Sebagai lembaga yang berusaha mewakili kepentingan masyakat; dan
d. Sebagai penghubung antara penguasa dan rakyat. ${ }^{7}$

Sementara itu, James Rosnau lebih menekankan kepada fungsi partai politik sebagai sarana penghubung antara berbagai macam kepentingan dalam suatu sistem politik. ${ }^{8}$ Dalam hal ini, menurutnya ada dua peranan penting partai politik dalam linkage politik, yakni: ${ }^{9}$

a. Sebagai institusi yang berfungsi penetratif (penetrative linkage), dalam arti sebagai lembaga yang ikut memainkan peranan dalam proses pembentukan kebijakan negara;

b. Sebagai reactive linkage, yaitu lembaga yang melakukan reaksi atas kebijakan yang dikeluarkan oleh negara.

Dalam negara demokrasi modern, fungsi partai politik secara umum adalah:

a. Partaipolitiksebagaisaranakomunikasi politik, yaitu di satu pihak merumuskan kepentingan dan menggabungkan atau menyalurkan kepentingan masyarakat untuk disampaikan dan diperjuangkan kepada pemerintah, sedangkan di pihak lain juga berfungsi menjelaskan dan menyebarluaskan kebijaksanaan pemerintah kepada masyarakat (khususnya anggota partai politik yang bersangkutan).

b. Partai politik sebagai sarana sosialisasi politik, yaitu proses dimana seseorang memperoleh pandangan, orientasi, dan nilai-nilai dari masyarakat dimana dia berada. Proses tersebut juga mencakup proses dimana masyarakat mewariskan norma-norma dan nilai-nilai dari satu generasi ke generasi berikutnya. Melalui kursus-kursus pendidikan, partai politik menanamkan nilai-nilai ideologi dan loyalitas kepada negara dan partai. Istilah sosialiasi politik merupakan istilah yang longgar pengertiannya, istilah yang ketat pengertiannya adalah pendidikan politik, sedangkan yang paling ketat disebut indokrrinasi politik.

c. Partai politik sebagai sarana rekrutmen politik, yaitu proses melalui mana

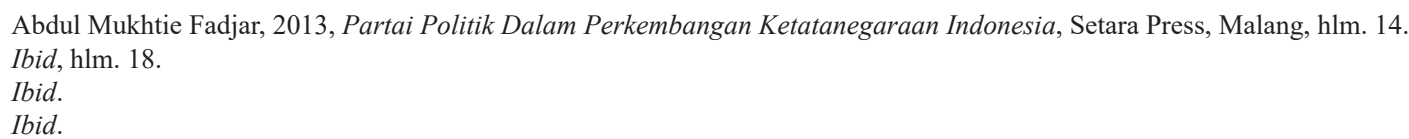


partai mencari anggota baru dan mengajak orang yang berbakat untuk berpartisipasi dalam proses politik. Rekrutmen politik akan menjamin kontinuitas dan kelestarian partai, dan sekaligus merupakan salah satu cara untuk menyeleksi para calon pimpinan partai atau pemimpin bangsa.

d. Partai politik sebagai sarana pengatur konflik, yaitu bahwa dalam negara demokratis yang masyarakatnya terbuka dan plural, perbedaan dan persaingan pendapat sangatlah wajar, akan tetapi sering menimbulkan konflik sosial yang sangat luas. Oleh karena itu, konflik harus bisa dikendalikan atau dijinakkan agar tidak berlarutlarut yang bisa menggoyahkan dan membahayakan eksistensi bangsa. Dalam hal ini, partai politik dapat berperan menekan konflik seminimal mungkin. ${ }^{10}$

\section{Sumber Penerimaan Partai Politik}

Secara umum, sumber penerimaan partai politik dalam sistem politik demokrasi berasal dari tiga pihak. Pertama, berasal dari sumber internal partai, seperti iuran anggota dan sumbangan dari kader partai yang duduk dalam pemerintahan dan lembaga legislatif. ${ }^{11}$

Kedua, berasal dari negara (APBN dan APBD) karena partai politik melaksanakan tugas publik, setidak-tidaknya mempersiapkan dan mengajukan calon anggota DPR dan DPRD, dan calon presiden dan calon kepala daerah, dan untuk menjamin persaingan yang adil antar-partai politik peserta pemilu atau antarcalon, sangat wajar pula apabila negara melalui APBN menyediakan public funding, baik yang dialokasikan secara langsung maupun tidak langsung, baik yang diberikan sebagai insentif bagi partai untuk menjalankan fungsinya maupun sebagai upaya menjamin modal dasar minimal yang sama antarpartai.

Ketiga, berasal dari kalangan masyarakat, baik individu perseorangan maupun organisasi

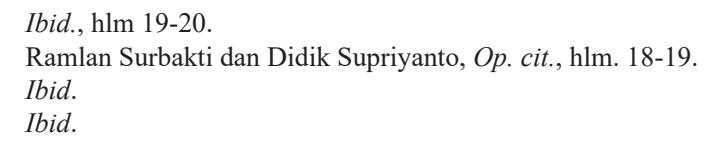

sosial dan badan usaha swasta. Untuk mencegah ketergantungan partai politik atau para calon kepada anggaran negara pada satu pihak dan pada pihak lain agar partai politik atau calon tetap menjalin hubungan interaktif dengan berbagai unsur masyarakat, sejumlah negara demokrasi membuka kesempatan bagi partai politik untuk mendapatkan sumbangan dari kalangan swasta (private funding). Namun, untuk mencegah ketergantungan partai politik pada kontribusi swasta, negara demokrasi ini mengenakan sejumlah pembatasan pada jumlah maksimal sumbangan, baik perseorangan dan organisasi maupun perusahaan swasta. ${ }^{12}$

Berdasarkan kajian komparasi, ternyata tidak semua negara mengadopsi ketiga sumber ini. Ada negara yang tidak melarang pemberian sumbangan individual tetapi membatasi jumlah sumbangan individual seperti Ceko dan Amerika Serikat, sedangkan ada sebagian negara seperti Brazil, India, Israel dan Meksiko yang hanya membatasi sumbangan dari donatur-donatur tertentu. Sementara itu Italia hanya membatasi sumbangan kepada individu yang mencalonkan diri tapi tidak kepada sumbangan langsung kepada partai politik, dan sebagian lagi membuka kesempatan bagi partai politik mendapatkan dana dari masyarakat dan negara dengan derajad keseimbangan yang berbeda antar negara, seperti Jerman dan Amerika Serikat. Tidak ada partai politik di negara demokrasi dewasa ini yang mengandalkan pembiayaan partai sepenuhnya dari iuran anggota. ${ }^{13}$

Pasal 34 Undang-Undang No. 2 Tahun 2008 dan Undang-Undang No. 2 Tahun 2011 menetapkan tiga jenis sumber keuangan partai politik, yaitu:

\section{Iuran anggota}

Undang-Undang No. 2 Tahun 2008 dan Undang-Undang No. 2 Tahun 2011, serta semua AD/ ART partai politik menyebut iuran anggota sebagai sumber pendapatan partai. Namun, prakteknya hampir semua partai politik tidak melakukan pengumpulan iuran 
anggota. Pencantuman iuran anggota dalam undang-undang dan peraturan organisasi, lebih merupakan warisan ketentuan lama daripada instrumen organisasi modern. Jika iuran anggota benar-benar hendak dilakukan, seharusnya partai politik membuat peraturan operasional atau peraturan teknis (berupa peraturan organisasi atau pedoman pengurus atau petunjuk teknis ketua/bendahara, atau bentuk lain), yang bisa digunakan sebagai pedoman menarik iuran anggota. Peraturan operasional ini menentukan berapa besaran iuran anggota, siapa yang berwenang mengumpulkan (dalam arti pengurus tingkat mana), bagaimana pembagiannya, serta bagaimana peruntukkannya. Semua itu tidak ada, sehingga ketentuan iuran anggota memang hanya pajangan undang-undang dan AD/ART. ${ }^{14}$ Hal ini menunjukkan bahwa tidak ada kesungguhan dari partai untuk menggalang dana dari anggotanya.

Berbeda dengan negara-negara lain, hampir semua negara, seperti Amerika Serikat, Jerman, Portugal, dan masih banyak lagi, yang menekankan bahwa sumber utama keuangan partai adalah iuran anggota. Mereka menyebutnya sebagai "Uang Jujur", karena anggota menyumbang bukan untuk mendapatkan imbalan keuntungan atau fasilitas, tetapi karena ingin agar idealismenya dan aspirasinya dibawakan oleh partai tempat dia menjadi anggota. ${ }^{15} \mathrm{Hal}$ ini sejalan dengan hasil survei International Republican Institute (IRI) 2008 bahwa hampir $60 \%$ pemilih ternyata mau memberikan sumbangan kepada partai politik. ${ }^{16}$ Indonesia perlu untuk mencontoh pengaturan tersebut. Partai politik dalam sistem politik demokrasi seharusnya dikelola berdasarkan prinsip demokrasi, yaitu dari, oleh, dan untuk anggota. Disebabkan partai politik dimiliki oleh seluruh anggota, dikelola oleh para anggota atau yang mewakilinya, baik secara langsung maupun tidak langsung, dan kegiatan partai diarahkan demi kepentingan para anggota, maka seharusnya sumber utama penerimaan dana partai politik dalam sistem politik demokrasi adalah iuran anggota. Iuran anggota ini dikenakan dalam jumlah yang sama untuk setiap anggota. Akan tetapi, wajar pula apabila kader partai yang duduk dalam lembaga legislatif ataupun lembaga eksekutif memberi sumbangan kepada partai dalam persentase tertentu yang ditetapkan partai.

\section{Sumbangan yang Sah Menurut Hukum}

Sumbangan yang sah menurut hukum adalah sumbangan dari perseorangan anggota, sumbangan dari perseorangan bukan anggota, sumbangan dari perusahaan dan/ atau badan usaha. Sumbangan yang sah menurut hukum adalah Sumbangan yang dimaksud dapat berupa uang, barang, dan/ atau jasa. Sumbangan dari perseorangan anggota partai pelaksanaannya diatur dalam AD/ART. Sumbangan dari perseorangan bukan anggota partai paling banyak senilai Rp 1.000.000.000,00 (satu miliar rupiah) per orang dalam waktu 1 (satu) tahun anggaran. Sedangkan, sumbangan dari perusahaan dan/ atau badan usaha paling banyak senilai $\mathrm{Rp}$ 7.500.000.000,00 (tujuh miliar lima ratus juta rupiah) per perusahaan dan/atau badan usaha dalam waktu 1 (satu) tahun anggaran.

\section{Bantuan keuangan dari APBN/ APBD}

Diberikan secara proporsional kepada partai politik yang mempunyai kursi di DPR/ DPRD berdasarkan jumlah perolehan suara.

4 Very Junaidi, et al., Op. cit, hlm 84.

15 Anonim, "Perbandingan Aturan-aturan Keuangan Partai Politik di Beberapa Negara", http://keuanganlsm.com/perbandingan-aturan-aturankeuangan-partai-politik-di-beberapa-negara/, diakses 27 Juni 2016.

16 Very Junaidi, et al., Op. cit., hlm. 85. 
Bantuan keuangan negara ini diprioritaskan untuk melaksanakan pendidikan politik bagi anggota partai politik dan masyarakat, yaitu yang berkaitan dengan kegiatan:

a. Pendalaman mengenai empat pilar berbangsa dan bernegara, yaitu Pancasila, UUD 1945, Bhineka Tunggal Ika, dan NKRI.

b. Pemahaman mengenai hak dan kewajiban warga negara Indonesia dalam membangun etika dan budaya politik.

c. Pengkaderan anggota partai politik secara berjenjang dan berkelanjutan.

4. Transparansi dan Akuntabilitas Pengaturan Keuangan Partai Politik

Uang merupakan kebutuhan mutlak untuk proses politik demokratis, dan partai politik harus memiliki akses terhadap dana untuk dapat berperan dalam proses politik. Proses politik demokratis tidak akan dapat berlangsung tanpa keuangan yang memadai. Partai politik tidak akan dapat mengorganisasi dirinya, para politikus tidak akan dapat berkomunikasi dengan publik, dan kampanye pemilu tidak akan dapat dilaksanakan bila mereka tidak memiliki dana yang memadai. Bahkan untuk konteks Indonesia, UUD Negara Republik Indonesia Tahun 1945 memberikan penugasan kepada partai politik, yaitu menjadi peserta Pemilu Anggota DPR dan DPRD dan menjadi pihak yang mengusulkan pasangan calon Presiden dan Wakil Presiden (dan belakangan UU menugaskan partai politik mengusulkan pasangan calon kepala daerah dan wakil kepala daerah). Dengan tugas ini, partai politik tidak hanya berarti badan publik, tetapi juga para kader partai politiklah yang menyelenggarakan tugas dan kewenangan lembaga legislatif dan eksekutif. Oleh karena itu, dana partai tidak hanya tak terhindarkan, tetapi juga diperlukan. Namun, bukan berarti partai politik di dalam mengumpulkan dana partai tanpa pengaturan. Harus ada regulasi yang mengatur mengenai hal tersebut.

Regulasi tentang keharusan transparansi laporan keuangan, misalnya, akan dapat membantu pengendalian pengaruh negatif uang dalam proses politik, tetapi regulasi ini juga perlu dipersiapkan dan diimplementasikan dengan baik. Pengawasan yang efektif terhadap regulasi keuangan partai tidak hanya tergantung pada aktivitas interaksi antarpemangku kepentingan (stakeholders), seperti regulator, organisasi masyarakat sipil, dan media massa, tetapi juga pelaksanaan prinsip transparansi tersebut. Peningkatan kesadaran publik tentang pentingnya pencegahan dan pemberantasan korupsi dalam keuangan partai politik sangat menentukan berfungsinya lembaga demokrasi.

Pengaturan keuangan partai politik harus dibedakan dengan pengaturan keuangan kampanye, meskipun dana kampanye tidak bisa dipisahkan dari keuangan partai politik karena kampanye Pemilu merupakan kelanjutan dari pelaksanaan fungsi partai politik, yaitu rekrutmen warga negara menjadi anggota partai, kaderisasi anggota menjadi kader partai, merumuskan rencana pola dan arah kebijakan publik berdasarkan aspirasi konstituen dan ideologi partai (representasi politik), dan nominasi kader partai menjadi calon pemimpin di lembaga legislatif atau eksekutif. Selain itu, salah satu sumber dana kampanye Pemilu adalah sumbangan dari kas Partai. ${ }^{17}$ Namun, keuangan partai politik yang perlu mendapat pengaturan adalah yang terkait dengan pendapatan dan belanja partai politik untuk membiayai kegiatan operasional partai politik sepanjang tahun. Kegiatan ini meliputi pembiayaan sekretariat, rapat-rapat partai, pendidikan politik dan kaderisasi serta kegiatankeigatan unjuk publik (public expose) yang betujuan menjaga eksistensi partai politik, seperti perayaan ulang tahun, seminar, kajian, aksi sosial, dan lainlain. Sedangkan, pengaturan keuangan kampanye 
mengatur pendapatan dan belanja kampanye yang berlangsung pada masa pemilu. Dalam hal ini semua transaksi keuangan yang dilakukan partai politik dan bertujuan mempengaruhi pemilih selama masa pemilu, diatur melalui pengaturan dana kampanye.

Prinsip pokok pengaturan keuangan partai politik adalah transparansi dan akuntabilitas. Prinsip transparansi mengharuskan partai politik bersikap terbukaterhadap semuaprosespengelolaankeuangan partai politik. Di sini sejumlah kewajiban harus dilakukan partai politik, seperti membuka daftar penyumbang dan membuat laporan keuangan secara rutin, yang mencatat semua pendapatan dan belanja partai politik sepanjang tahun. Tujuan membuka daftar penyumbang dan laporan keuangan kepada publik adalah untuk menguji prinsip akuntabilitas, yaitu memastikan tanggungjawab partai politik dalam proses menerima dan membelanjakan dana partai politik secara rasional, sesuai etika dan tidak melanggar peraturan.

Kewajiban untuk membuat laporan keuangan sebenarnya sudah diatur dalam Undang-Undang No. 2 Tahun 2011, yang kemudian diatur lebih dalam Peraturan Pemerintah No. 5 Tahun 2009 tentang Bantuan Keuangan Partai Politik. Namun, aturan tersebut tidak dipergunakan secara luas dan tidak diimplementasikan dengan tegas. Di sini, penulis mencoba untuk memberikan beberapa rekomendasi terkait pengaturan keuangan partai politik ke depannya. Pertama, disyaratkan setiap partai politik, baik di tingkat pusat hingga tingkat daerah membuat laporan keuangan tahunan yang diumumkan ke publik dan diaudit oleh auditor eksternal. Laporan keuangan harus dipisahkan antara pendapatan yang berasal dari APBN/APBD dan yang berasal dari sumber di luar APBN/APBD. Selain itu, juga perlu membuat standar laporan keuangan partai politik yang sangat rinci dalam Undang-Undang Pemilu dalam rangka menjamin transparansi penerimaan dan pengeluaran partai politik.

Undang-Undang No. 2 Tahun 2011 sudah mengatur bahwa partai politik wajib menyampaikan laporan pertanggungjawaban penerimaan dan pengeluaran yang bersumber dari bantuan APBN dan APBD kepada BPK secara berkala 1 (satu) tahun sekali untuk diaudit paling lambat 1 (satu) bulan setelah tahun anggaran berakhir (Pasal 34A). Selain itu, pada Pasal 39 juga sudah diatur bahwa pengelolaan keuangan partai politik dilakukan secara transparan dan akuntabel dengan membuat laporan keuangan untuk keperluan audit dana oleh akuntan publik setiap 1 (satu) tahun dan diumumkan secara periodik. Laporan keuangan yang harus dibuat secara periodik ini pun harus diatur secara jelas terdiri dari apa saja. Laporan keuangan periodik bisa diatur terdiri dari: laporan posisi keuangan, laporan aktifitas, laporan arus kas, dan catatan atas laporan keuangan. Menurut penulis, sebaiknya tidak hanya ada kewajiban membuat laporan keuangan partai secara periodik saja, tetapi juga kewajiban membuat laporan keuangan Pemilu, terutama pertanggungjawaban dana kampanye.

Hampir semua negara di Afrika mewajibkan partai politik dalam membuat laporan keuangan dengan persyaratan, yaitu pelaporan harus cukup rinci memuat analisis yang efektif, meskipun tidak menuntut untuk mematuhinya yang membuat partai-partai politik beralasan untuk tidak membuat laporan keuangan. Namun, banyak negara juga hanya membutuhkan laporan keuangan, baik dari pihak partai politik, calon, atau tidak dari keduanya. Memang, hanya 17 negara Afrika memiliki kedua jenis persyaratan pelaporan. Di beberapa negara lain, laporan keuangan partai harus menyertakan pendapatan dan belanja calon yang diusulkan untuk dikeluarkan secara independen dari partai. Namun, di Afrika sendiri sedikit partai politik memiliki kapasitas administratif untuk mengumpulkan dan memverifikasi informasi-informasi tersebut.

Memang, mekanisme pelaporan dana partai ke publik membuat pendonor dana takut sehingga mengakibatkan mereka tidak akan memberikan donor keuangan kembali kepada partai politik. Namun, tanpa laporan tersebut, memastikan transparansi dan kepatuhan terhadap peraturan lainnya secara efektif tidak mungkin, meskipun penyampaian laporan seperti ini tentu saja tidak ada 
jaminan bahwa tujuan akan tercapai karena laporan tersebut mungkin saja tidak benar. Oleh karena itu, ada beberapa negara di Afrika yang membuat pengaturan, yaitu untuk meminta sumbangan di atas batas tertentu harus dilaporkan. Misalnya, di Liberia dan Lesotho. Sumbangan di bawah $\$ 10$ hanya dilaporkan dalam bentuk ringkasan, sedangkan dalam sumbangan di atas $\$ 44,000$ harus dilaporkan ke Komisi Pemilu dalam waktu tujuh hari sejak diterima sumbangan tersebut. ${ }^{18}$ Sekiranya Indonesia bisa mencontoh pengaturan pelaporan keuangan partai politik seperti di Afrika tersebut.

Meskipun sudah ada pengaturan kewajiban membuat laporan keuangan partai, di dalam Undang-Undang Pemilu maupun Undang-Undang Partai Politik belum mengatur mengenai standar laporan keuangan partai politik. Dengan diaturnya standar laporan keuangan partai politik, maka akan terjadi keseragaman pemahaman antar partai politik mengenai pembuatan laporan keuangan partai. Jika pun partai politik berkehendak membuat laporan, mereka mengalami kesulitan karena tidak adanya format laporan keuangan yang harus mereka buat. Hal ini berbeda dengan Undang-Undang No. 2 Tahun 1999 dan Undang-Undang No. 31 Tahun 2002 yang diikuti oleh pedoman penyusunan laporan keuangan tahunan partai politik yang masing-masing disusun oleh MA dan KPU. Undang-Undang No. 2 Tahun 2011 menyebutkan partai politik wajib membuat laporan keuangan untuk keperluan audit dana meliputi: (a) laporan realisasi anggaran partai politik; (b) laporan neraca, dan; (c) laporan arus kas. Bagi kalangan keuangan, apa yang dimaksud dengan laporan realisasi anggaran partai politik, laporan neraca, dan laporan arus kas, mungkin sudah jelas. Namun, belum tentu pengurus partai politik mengerti betul apa yang dimaksud dengan ketentuan-ketentuan tersebut, meskipun rumusan undang-undang itu dibuat oleh wakil-wakil partai politik di DPR.

Selain itu, guna memudahkan proses auditing, laporan realisasi anggaran partai politik, laporan neraca, dan laporan arus kas membutuhkan format standar. Mengenai siapa yang membuat format laporan ini, undang-undang tidak menyebutkannya. Dalam rangka mendapatkan laporan keuangan yang kredibel juga diperlukan sistem kelola keuangan yang baku. Standar laporan keuangan partai harus diatur mengenai: (a) sumber penerimaan partai, termasuk di dalamnya identitas lengkap setiap sumber penerimaan, jenis dan jumlah sumber penerimaan, (b) pembangunan unit usaha, (c) batasan jumlah biaya kampanye, (d) pemisahan dana rutin dan dana kampanye, (e) pengaturan dana rutin, (f) keterbukaan laporan keuangan, (g) keterbukaan dana partai, dan (h) sanksi atas pelanggaran aturan.

Selain pengaturan kewajiban membuat laporan keuangan partai dan laporan Pemilu, juga perlu mewajibkan partai politik membuat daftar penyumbang dan menyimpan laporan tersebut dalam file agar bisa diakses oleh publik. Keterbukaan tidak hanya berlaku bagi penerimaan yang bersumber dari APBN dan APBD saja, tetapi juga sumbangansumbangan lain yang diterima partai, karena Pasal 35 ayat (2) Undang-Undang No. 2 Tahun 2011 sudah mengatur bahwa sumbangan yang diterima partai politik didasarkan pada prinsip kejujuran, sukarela, keadilan, terbuka, tanggungjawab, kedaulatan, dan kemandirian partai politik. Hampir semua negara mewajibkan partai politiknya untuk mengumumkan kepada publik jumlah sumbangan dan daftar sumbangan yang diterima partai politik kepada publik. Argentina membolehkan tidak diumumkan sampai jangka waktu 3 (tiga) tahun setelah Pemilu berlalu. Afrika Selatan tidak mewajibkan keterbukaan ini tetapi publik bisa mendapatkan informasi mengenai keuangan partai politik lewat undang-undang hak atas informasi. Indonesia bisa mencontoh pengaturan hukum dari negara-negara lain terkait keterbukaan dana partai yang diterima. Selain itu, juga dalam Pasal 28F UUD NRI Tahun 1945 disebutkan bahwa setiap orang berhak untuk

18 Magnus Ohman, 2014, Regional Studies on Political Finance: Regulatory Frameworks and Political Realities, International IDEA, Sweden, hlm. 59 . 
berkomunikasi dan memperoleh informasi untuk mengembangkan pribadi dan lingkungan sosialnya, serta berhak untuk mencari, memperoleh, memiliki, dan menyimpan informasi dengan menggunakan segala jenis saluran yang tersedia. Hak untuk memperoleh informasi merupakan hak asasi manusia sebagai salah satu wujud dari kehidupan berbangsa dan bernegara yang demokratis.

Kedua, pada pasal 39 Undang-Undang No. 2 Tahun 2011 mengatur bahwa pengelolaan keuangan partai politik yang diaudit oleh akuntan publik akan diumumkan secara periodik. Kemudian, pada bagian penjelasan pasal 39 disebutkan bahwa pengumuman tersebut dilakukan melalui media massa. Di banyak negara demokrasi lain, lembaga pengawasan dana politik berhak dan mempunyai kepentingan untuk mengumumkan laporan yang mereka terima dari parpol dan peserta pemilu. Untuk mengumumkan laporan tersebut, mereka pada umumnya memakai jasa internet. Dengan demikian, media dan masyarakat umum bisa memeriksa apakah data yang dilaporkan oleh parpol sesuai dengan apa yang mereka amati sendiri di lapangan. Misalnya, FEC (Federal Election Commission) di Amerika Serikat sering memulai proses investigasi terhadap seorang calon hanya setelah mendapatkan pengaduan dari masyarakat bahwa laporan resmi yang dipublikasikan di internet tidak sesuai dengan fakta sebenarnya.

Perbandingan dengan Jerman, laporan keuangan parpol juga dipublikasikan di internet, dan kemungkinan pelanggaran bisa dilaporkan langsung kepada kantor Ketua DPR, yang di Jerman bertanggungjawab atas pengawasan dana parpol. ${ }^{19}$ Oleh karena itu, sekiranya Indonesia bisa mengikuti contoh negara demokrasi tersebut dan membuat beberapa peraturan baru yang mengatur penggunaan internet (misalnya, melalui website KPU) sebagai salah satu unsur utama pengawasan dana politik. Dengan adanya publikasi melalui website maupun media massa, undang-undang perlu memberikan kewenangan kepada KPU untuk dapat melakukan penyelidikan lebih lanjut bila ditemukan bukti awal penyimpangan dalam hasil audit tersebut, yang kemudian KPU bisa meneruskan laporan tersebut kepada penegak hukum apabila penyimpangan tersebut termasuk kategori pidana pemilu. KPU dapat mengenakan sanksi sesuai dengan undangundang jika penyimpangan tersebut termasuk kategori pelanggaran administrasi pemilu.

Ketiga, perlu dibentuk lembaga pengawasan mengontrol kesungguhan partai politik dalam memenuhi kewajiban membuat laporan keuangan tahunan. Undang-Undang No. 2 Tahun 2011 belum mengatur kewajiban partai politik untuk menyampaikan laporan keuangan tahunan itu kepada institusi manapun. Memang, di dalam Pasal 14 Peraturan Pemerintah No. 5 Tahun 2009 diatur bahwa laporan pertanggungjawaban penerimaan dan pengeluaran keuangan yang bersumber dari dana bantuan APBN/APBD secara berkala 1 (satu) tahun sekali disampaikan kepada:

1. Pemerintah melalui Menteri Dalam Negeri oleh Partai Politik tingkat pusat;

2. Gubernur oleh Partai Politik tingkat provinsi; dan

3. Bupati/walikota oleh Partai Politik tingkat kabupaten/kota.

Namun, hal itu hanya berlaku bagi sumber dana bantuan berasal dari APBN dan APBD, sedangkan untuk laporan pertanggungjawaban sumber dana yang berasal dari iuran anggota dan sumbangansumbangan tidak diatur lembaga mana yang diberikan laporan pertanggungjawaban tersebut. Oleh karena itu, apabila di kemudian hari dibentuk Peraturan Pemerintah sebagai peraturan pelaksanaan dari Undang-Undang No. 2 Tahun 2011 bisa diatur lebih terperinci lagi lembaga mana yang akan diserahi laporan keuangan dari sumber-sumber dana yang diperoleh partai politik. Selain itu, juga perlu melibatkan pihak LSM yang mewakili elemen 
masyarakat dalam mengawasi transparansi dan akuntabilitas pengelolaan keuangan partai politik.

Tujuan adanya lembaga yang melakukan pengawasan terhadap laporan keuangan partai politik adalah untuk memudahkan mekanisme kontrol serta penjatuhan sanksi terhadap partai politik yang tidak memenuhi kewajiban membuat laporan keuangan tahunan, karena akan segera diketahui partai politik mana yang telah menunaikan kewajiban membuat laporan keuangan tahunan, dan partai politik mana yang tidak membuat laporan keuangan tahunan.

Keempat, pengaturan mengenai sanksi yang dijatuhkan bagi partai politik yang tidak membuat laporan keuangan partai diperlukan ada. Undang-Undang No. 2 Tahun 2011 belum mengatur mengenai sanksi yang tegas bagi partai politik yang tidak membuat laporan keuangan partai. Bahkan, beberapa pengurus partai politik yang mengikuti diskusi terbatas untuk membahas masalah ini, mengakui pihaknya tidak pernah mengetahui keberadaan laporan keuangan tersebut. Mestinya hal itu diketahui bendahara partai politik, tetapi ketika bendahara partai politik ditanyakan itu, jawabannya tidak tahu juga. Pada acara-acara resmi partai politik, seperti mukernas atau rakernas, atau rapat DPP yang digelar setiap bulan, juga tidak pernah membahas tentang laporan keuangan partai politik. Tidak heran jika dalam dikusi terbatas dengan pengurus partai politik, beberapa pengurus partai politik mengaku terang-terangan partainya tidak pernah membuat laporan keuangan tahunan. ${ }^{20}$

Pasal 47 Undang-Undang No. 2 Tahun 2011 sudah mengatur mengenai sanksi bagi partai politik yang tidak menyampaikan laporan pertanggungjawaban penerimaan dan pengeluaran keuangan yang bersumber dari dana bantuan APBN dan APBD secara berkala 1 (satu) tahun sekali, yaitu dikenai sanksi administratif berupa penghentian bantuan APBN dan APBD sampai laporan diterima oleh pemerintah dalam tahun anggaran berikutnya.
Namun, sanksi tersebut hanya berlaku bagi keuangan partai yang bersumber dari dana bantuan APBN dan APBD, sedangkan sumber dana partai politik tidak hanya berasal dari negara saja, tetapi juga ada dari iuran anggota dan sumbangan-sumbangan. Sumber dana berupa sumbangan-sumbangan inilah yang perlu mendapat perhatian.

Jimly Asshiddiqie mengatakan pengelolaan dana partai politik ini tak sekedar terbuka, tapi juga harus disertai dengan sanksi yang mengikat. Sanksi seperti pembekuan sampai pembubaran partai politik juga harus diberikan kepada partai politik yang tidak transparan pengelolaan dananya. ${ }^{21}$ Sebagian besar negara memberlakukan sanksi administratif terhadap partai politik yang melanggar aturan-aturan keterbukaan laporan keuangan dan dana partai. Sanksi administratif ini dari mulai yang terberat, seperti dibubarkannya partai, yang sedang seperti tidak dizinkan mengikuti Pemilu atau yang ringan seperti tidak mendapatkan subsidi dari negara. Sebagian besar negara juga memberlakukan sanksi pidana terhadap pelanggaran-pelanggaran ini dan prosesnya melalui pengadilan pidana. Negara-negara yang memberlakukan sanksi pidana ini antara lain Amerika Serikat, Inggris, Jerman, Ceko, Kanada, Portugal, Filipina dan Thailand. Di Indonesia perlu ada pengaturan sanksi bagi partai politik yang tidak membuat laporan keuangan partai dan yang terlambat membuat laporan keuangan tersebut, apakah berupa sanksi administratif, misalnya bisa sampai pemberlakuan sanksi berupa tidak bisa menjadi peserta pemilu yang selanjutnya, atau bisa sanksi pidana.

Sanksi pidana menjadi sesuatu yang tidak mustahil untuk diberlakukan bagi partai politik yang tidak menerapkan transparansi penggunaan dana. Indonesia telah mempunyai sanksi pidana terhadap badan hukum (korporasi). Partai politik merupakan badan hukum yang menjadi subyek hukum. Seperti yang lazim diatur dalam sistem hukum berbagai negara, dalam Article 2 clause 
1 Undang-Undang tentang Partai Politik Jerman (sebagai contoh), juga ditentukan "Parties are associations of citizens.. [...] Party members may only be natural persons" (Partai politik adalah asosiasi warga negara dan karena itu dapat berstatus sebagai badan hukum (rechtspersoon). Akan tetapi, sebagai badan hukum, partai politik itu tidak dapat beranggotakan badan hukum yang lain. Yang hanya dapat menjadi anggota badan hukum partai politik adalah perorangan warga negara sebagai natuurlijke persoons. ${ }^{22}$ Status partai politik sebagai badan hukum itu sangat penting dalam hubungan dengan kedudukan partai politik itu sebagai subyek dalam lalu lintas hukum. Oleh karena itu, sebagai subyek hukum, partai politik dapat dikenakan sanksi pidana korporasi apabila melanggar norma-norma hukum yang berlaku terkait transparansi pemasukan dan pengeluaran partai.

Pemberlakuan sanksi yang tidak diimbangi dengan kesadaran dari anggota partai politik dan pengawasan dari semua elemen masyarakat menjadi sesuatu hal yang mustahil untuk dilakukan. Oleh karena itu, pemerintah perlu terus melakukan sosialisasi kepada anggota partai politik, khususnya pengurus partai politik mengenai pentingnya prinsip keterbukaan dan akuntabilitas dalam pengelolaan keuangan partai, karena akan memberikan kepercayaan kepada stakeholders, khususnya kepada publik. Dengan kepercayaan publik, maka organisasi partai politik menjadi kuat.

\section{Penutup}

Praktek penggalangan dana oleh partai politik yang tidak dilandasi dengan prinsip transparansi dan akuntabilitas mengakibatkan munculnya berbagai kasus dugaan korupsi yang dilakukan orang partai politik. Banyak kasus korupsi yang terungkap menunjukkan bahwa dana dari kejahatan itu digunakan untuk kepentingan pemenangan pemilu, baik di tingkat nasional maupun lokal. Hal ini menjadi salah satu penyebab dari buruknya kualitas Demokrasi di Indonesia. Oleh karena itu, perlu dilakukan reformasi pengaturan keuangan partai politik ke depannya yang memenuhi prinsip transparansi dan akuntabilitas. Prinsip transparansi dan akuntabilitas keuangan partai bisa dicapai dengan cara mewajibkan setiap partai politik membuat laporan keuangan atas sumber-sumber dana yang diterima oleh partai, baik dana yang bersumber dari anggota partai, dari APBN dan APBD, maupun dari sumbangan-sumbangan pihak lain.

Selain itu, juga perlu mewajibkan untuk membuat laporan keuangan Pemilu, termasuk di dalamnya dana kampanye. Pembuatan laporan keuangan tersebut juga perlu ada pedoman/standar laporan keuangan partai, sehingga akan terjadi keseragaman pemahaman antar partai politik. Namun, pengaturan mengenai kewajiban membuat laporan keuangan partai juga perlu diimbangi dengan pengaturan sanksi yang tegas bagi partai politik yang terlambat atau tidak membuat laporan keuangan partai, dan diatur lembaga yang melakukan pengawasan terhadap laporan keuangan tersebut serta lembaga yang menegakkan sanksi tersebut. Pengaturan itu semua perlu diadopsi pada UndangUndang Pemilu dan Undang-Undang Partai Politik, sehingga disarankan agar pembentuk undangundang segera melakukan perubahan terhadap Undang-Undang Pemilu dan Undang-Undang Partai Politik dengan memasukkan pengaturanpengaturan tersebut di atas.

\section{DAFTAR PUSTAKA}

A. Buku

Asshiddiqie, Jimly, 2006, Kemerdekaan Berserikat, Pembubaran Partai Politik, dan Mahkamah
Konstitusi, Sekretariat Jenderal dan Kepaniteraan Mahkamah Konstitusi RI, Jakarta.

22 Jimly Asshiddiqie, 2006, Kemerdekaan Berserikat, Pembubaran Partai Politik, dan Mahkamah Konstitusi, Sekretariat Jenderal dan Kepaniteraan Mahkamah Konstitusi RI, Jakarta, hlm 69. 
Budiardjo, Miriam, 2005, Dasar-dasar Ilmu Politik, Gramedia Pustaka Utama, Jakarta.

Fadjar, Abdul Mukhtie, 2013, Partai Politik Dalam Perkembangan Ketatanegaraan Indonesia, Setara Press, Malang.

Junaidi, Very, et al., 2011, Anomali Keuangan Partai Politik: Pengaturan dan Praktek, Kemitraan bagi Pembaruan Tata Pemerintahan, Jakarta.

Ohman, Magnus, 2014, Regional Studies on Political Finance: Regulatory Frameworks and Political Realities, International IDEA, Sweden.

Surbakti, Ramlan, 2015, Roadmap Pengendalian Keuangan Partai Politik Peserta Pemilu, Kemitraan bagi Pembaharuan Tata Pemerintahan, Jakarta.

Surbakti, Ramlan dan Supriyanto, Didik, 2011, Pengendalian Keuangan Partai Politik, Kemitraan bagi Pembaruan Tata Pemerintahan, Jakarta.

\section{B. Artikel Jurnal}

Manurung, Torang Rudolf Effendi, "Perkembangan Politik Hukum Pertanggungjawaban Partai Politik Dalam Pengelolaan Bantuan
Keuangan Negara Pasca Reformasi”, Jurnal Yustisia, Vol. 91 Januari, April 2015.

Kelompok Kerja Reformasi Pendanaan Parpol dan Kampanye, "Reformasi Sistem Pendanaan Parpol dan Kampanye di Indonesia", Jurnal Pemilu \& Demokrasi, Vol. 3, Mei 2012.

\section{Hasil Penelitian}

Tim Riset Institute For Strategic Initiatives (ISI), Penggunaan Dana Publik Untuk Kampanye, Hasil Penelitian Tim Riset Institute For Strategic Initiatives (ISI) kerjasama dengan Kemitraan Partnership dan Perludem, Jakarta.

\section{E. Internet}

Anonim, "Perbandingan Aturan-aturan Keuangan Partai Politik di Beberapa Negara", http:// keuanganlsm.com/perbandingan-aturanaturan-keuangan-partai-politik-dibeberapa-negara/, diakses 27 Juni 2016.

Rochmi, Muhammad Nur, "Keterbukaan Pengelolaan Keuangan Parpol Diusulkan masuk RUU Pemilu", https://beritagarid/ artikel/berita/keterbukaan-pengelolaankeuangan-parpol-diusulkan-masuk-ruupemilu, diakses 27 Juni 2016. 